\title{
Soil Fertility, Growth and Productivity of Fenugreek (Trigonella foenum-graecum L.) as Influence by Fertilizer Levels, Biofertilizers and Brassinosteroid
}

\author{
A.S. Godara ${ }^{1 *}$, Ravindra Singh ${ }^{2}$ and G.S. Chouhan ${ }^{3}$ \\ ${ }^{1}$ ARSS, SKRAU, Shriganganagar, Rajasthan, India \\ ${ }^{2}$ ICAR-National Research Centre on Seed Spices, Ajmer, Rajasthan-305 206, India \\ ${ }^{3}$ MPUAT, Udaipur, Rajasthan, India \\ *Corresponding author
}

\section{A B S T R A C T}

Keywords

Biofertilizers, Brassinosteroid, Fenugreek, Fertility level

Article Info

Accepted:

06 August 2018

Available Online:

10 September 2018

\begin{abstract}
A field experiment was conducted during rabi seasons of 2012-13 and 2013-14 to find out the effect of fertility levels, biofertilizers and brassinosteroid on fenugreek productivity and soil fertility. Three fertility levels [60, 80 and $100 \% \mathrm{RDF}\left(40 \mathrm{~kg} \mathrm{~N}+40 \mathrm{~kg} \mathrm{P} \mathrm{P}_{2} \mathrm{O}_{5}+10\right.$ $\mathrm{kg} \mathrm{S} / \mathrm{ha}$ )] and three biofertilizer inoculations (Rhizobium, PSB and Rhizobium + PSB) in main plot and three concentrations of brassinosteroid (water spray, BR $0.25 \mathrm{ppm}$ and BR $0.50 \mathrm{ppm}$ ) in sub plot were studied in split plot design with three replications. The significantly highest values of growth parameters, nodules/plant, yield attributes, seed yield $(2245 \mathrm{~kg} / \mathrm{ha})$ and haulm yield $(5236 \mathrm{~kg} / \mathrm{ha})$ and soil fertility parameters after crop harvest viz., OC $(0.321 \%)$, available $\mathrm{N}, \mathrm{P}$ and $\mathrm{S}$ were recorded with application of $100 \%$ RDF over lower fertility levels. Dual inoculation of seed with Rhizobium + PSB gave significantly higher growth, nodules/plant, yield attributes, seed yield (2085 kg/ha) and OC $\%$, available $\mathrm{N}, \mathrm{P}$ and $\mathrm{S}$ over their sole application. Interaction of fertility levels and biofertilizers was also found significant in yield attributes and consequently in seed yield. Application of $100 \% \mathrm{RDF}+$ dual inoculation, being on a par with $80 \% \mathrm{RDF}+$ dual inoculation, gave the highest seed yield (2287 kg/ha). Foliar spray of brassinosteroid 0.50 ppm brought about significantly higher plant height $(69.08 \mathrm{~cm})$, branches/plant $(5.48)$, yield attributes and seed yield (2098 kg/ha) over water spray and BR $0.25 \mathrm{ppm}$, however; its impact on soil fertility was non-significant. Thus, addition of $80 \%$ RDF with dual inoculation and supplemented with foliar spray of brassinosteroid $0.50 \mathrm{ppm}$ at 50 and 70 DAS is better for attaining higher fenugreek yield and soil health.
\end{abstract}

\section{Introduction}

Fenugreek (Trigonella foenum-graecum L.) known as Methi is an important annual herbaceous winter season seed spice crop of north India particularly of Rajasthan. The seed is mainly used as condiment and seasoning agent for garnishing and flavouring dishes further it has immense medicinal value and is a good source of vitamins, protein and essential oils. Every part of its plant is useful. It also plays pivotal role in agricultural economy as it has bright export potential and is earning valuable foreign currency for the 
country. Rajasthan occupies prime position (77.03\% share) in fenugreek production, contributing 190360 tonnes in nation fenugreek production during 2015-16. However, productivity $(1127 \mathrm{~kg} / \mathrm{ha})$ of fenugreek in the country is quite below its potential yield (2500 $\mathrm{kg} / \mathrm{ha}$, Anonymous 2017). Cultivation on inherent poor soils with inadequate nutrition without biofertilizers inoculation and poor flowering and pod setting were considered to be the most important limiting factor (Khariya and Singh, 2003). Thus to sustain the productivity and being a legume to enhance soil fertility of hungry soil of Rajasthan, judicious use of fertilizer with integration of bio-fertilizers is important (Bhunia et al., 2006) and to regulate physiological processes for balancing source and sink to enhance flowering and pod setting exogenous application of plant bioregulator, particularly brassinosteroid plays vital role. Keeping these views, a study was carried out to assess the impact of fertilizer levels, biofertilizers and brassinosteroid on productivity of fenugreek and soil fertility.

\section{Materials and Methods}

A field experiment was carried out during rabi season of 2012-13 and 2013-14 on sandy loam soil at National Research Centre on Seed Spices, Ajmer (Rajasthan). The soil of the experimental site was sandy loam with a $\mathrm{pH}$ 8.03 having low organic carbon $(0.28 \%)$, low available nitrogen $(151.3 \mathrm{~kg} / \mathrm{ha})$, low available phosphorus $(7.8 \mathrm{~kg} / \mathrm{ha})$ and medium available potassium $(197.1 \mathrm{~kg} / \mathrm{ha})$. The experiment was laid out in split plot design comprising three levels of fertilizer $\left(\mathrm{F}_{1}-60 \% \mathrm{RDF}, \mathrm{F}_{2}-80 \%\right.$ $\mathrm{RDF}$ and $\mathrm{F}_{3}-100 \%$ RDF) and three biofertilizer inoculation ( $\mathrm{B}_{1}$-Rhizobium, $\mathrm{B}_{2-}$ $\mathrm{PSB}$ and $\mathrm{B}_{3}-$ Rhizobium + PSB) as main plot and three concentrations of brassinosteroid $\left(\mathrm{G}_{0}\right.$ - water spray, $\mathrm{G}_{1}-\mathrm{BR} 0.25 \mathrm{ppm}$ and $\mathrm{G}_{2}-\mathrm{BR}$ $0.50 \mathrm{ppm})$ as sub plot treatment replicated thrice. Recommended dose of fertilizer (RDF) comprised of $40 \mathrm{~kg} \mathrm{~N}+40 \mathrm{~kg} \mathrm{P}_{2} \mathrm{O}_{5}$ and $10 \mathrm{~kg}$ $\mathrm{S} / \mathrm{ha}$. Sowing of fenugreek (RMt-143) using $20 \mathrm{~kg} \mathrm{seed} / \mathrm{ha}$ was done at $30 \mathrm{~cm}$ line to line spacing. Seed treatment with Rhizobium meliloti, PSB and combination of both was done as per treatment before sowing. Full dose of nitrogen, phosphorus and sulphur was applied at the time of sowing. The nitrogen, phosphorus and sulphur were supplied through urea, DAP and gypsum, respectively. Brassinosteroid was sprayed twice at 50 and 70 DAS as per treatment under study. Five plants were selected randomly from each plot for taking biometric observations. Yield observations were recorded to evaluate the effect of treatments. Soil was analysed before sowing and after experiment for determination of OC $\%$ and available N, P and S. The data were statistically analysed as per procedure suggested by Panse and Sukhatme (1985).

\section{Results and Discussion}

\section{Growth and yield}

Addition of graded dose of fertility resulted in significant increase in plant height, branches/plant and nodules/plant. Application of $100 \% \mathrm{RDF}$ recorded highest plant height $(70.27 \mathrm{~cm})$, branches/plant (5.92) and nodules/plant (10.84) which was significantly higher over 80 and $60 \%$ RDF. At the same time aforesaid parameters were significantly higher under $80 \%$ RDF over $60 \%$ RDF. The significant improvement in $\mathrm{N}, \mathrm{P}$ and $\mathrm{S}$ status of soil resulted in better availability of nutrient for growth and development of nodules/plant, which helps in absorption and translocation of nutrients from vegetative to reproductive parts. The better nutritional environment in plant seems to have promoted branches/plant, height and dry matter/plant by way of active cell division and elongation. Results corroborated with findings of Ali et al., (2009) and Singh et al., (2010). A significant improvement in pods/plant, seeds/pod, seed 
weight/pod, pod length and 1000 seed weight of fenugreek were recorded with each successive increment in fertility level. All these yield attributes were maximum at $100 \%$ RDF. Favourable effects of yield attributes resulted in significant yield increase at each level of fertility. The maximum seed (2245 $\mathrm{kg} / \mathrm{ha})$ and haulm yield (5236 kg/ha) were recorded at $100 \% \mathrm{RDF}$. The increment in seed yield was 586 and $245 \mathrm{~kg} / \mathrm{ha}$ over 60 and $80 \% \mathrm{RDF}$, respectively, the corresponding increase in haulm yield was 559 and 302 $\mathrm{kg} / \mathrm{ha}$. Physiological role of $\mathrm{N}, \mathrm{P}$ and $\mathrm{S}$ in enhancing growth parameters might have led to increased yield attributes and thereby yield of crop at higher levels of fertility. Bhunia et al., (2006); Godara et al., (2017) and Kumar et al., (2009) also reported similar results.

Amongst inoculation, dual inoculation of Rhizobium and PSB improved growth and yield parameters over their sole application. The highest plant height $(68.50 \mathrm{~cm})$, branches/plant (5.50) and nodules (10.03) were recorded under dual inoculation which was significantly higher over single inoculation of PSB, however, it remained on a par with Rhizobium alone. At the same time Rhizobium alone also produced significantly taller plants, more branches and nodules over PSB alone (Table 1).

At later stage PSB and Rhizobium alone found on a par with each other. Combined inoculation recorded highest values of pods/plant (35.96), pod length $(12.13 \mathrm{~cm})$, seeds/pod (15.33) and seed weight/pod (0.210 g) which was significantly higher over single application of Rhizobium and PSB. Similarly highest 1000-seed weight (14.68 g) was recorded under dual inoculation which was significantly higher over Rhizobium and PSB alone by 5.6 and $8.2 \%$. Inoculation with Rhizobium + PSB resulted in highest seed (2085 kg/ha) and haulm yield (4941 kg/ha) which were significantly higher over
Rhizobium and PSB alone by 7.8 and 10.6, and 7.5 and $14.7 \%$, respectively. Concomitantly sole Rhizobium found on a par with sole PSB in almost all yield attributes and haulm and seed yield. The better performance of dual inoculation might be on account of associative effect of both symbiotic and asymbiotic bacteria. These results are in accordance with the findings of Purbey and Sen (2007) and Mehta et al., (2012).

Interaction effect between fertility levels and biofertilizers in respect of pods/plant, pod length, seeds/pod and seed weight/pod and thereby seed yield were observed significant (Table 2 and 3). The maximum values of aforesaid yield attributes were recorded under $100 \% \mathrm{RDF}+$ dual inoculation which were found on a par with $80 \% \mathrm{RDF}$ and dual inoculation. Statistically equally good performance of combination of $80 \% \mathrm{RDF}+$ dual inoculation was might be due to relatively better bacterial activity at lower fertility level. It is well established that $\mathrm{N}$ fixation decreases at higher levels of nitrogen.

Foliar spray of graded concentration of brassinosteroid (BR) resulted in significant increase in plant height and branches/plant. Spray of $0.50 \mathrm{ppm}$ BR recorded highest plant height $(69.08 \mathrm{~cm})$ and branches/plant (5.48) which was significantly higher over $0.25 \mathrm{ppm}$ and water spray. However, nodules/plant were remained unaffected due to foliar spray of brassinosteroid. A significant improvement in pods/plant, pod length, seeds/pod and 1000 seed weight of fenugreek were recorded with each higher concentration of brassinosteroid up to $0.50 \mathrm{ppm}$. Spray of BR $0.50 \mathrm{ppm}$ gave 8.3 and 3.7, 9.7 and 4.0, 3.8 and 1.8, and 16.0 and 6.2 per cent higher pods/plant, seeds/pod, 1000-seed weight and seed yield /plant over water spray and BR 0.25 ppm, respectively. Favourable effect of yield attributes resulted in significant yield increase at each higher concentration of brassinosteroid. 
Table.1 Growth, yield attributes and yield of fenugreek as influenced by fertility levels, biofertilizers and brassinosteroids

\begin{tabular}{|c|c|c|c|c|c|c|c|c|c|c|}
\hline Treatments & $\begin{array}{c}\text { Plant height at } \\
\text { harvest } \\
(\mathrm{cm})\end{array}$ & $\begin{array}{c}\text { Branches/ } \\
\text { plant at } \\
\text { harvest }\end{array}$ & $\begin{array}{c}\text { Nodules/ } \\
\text { plant }\end{array}$ & $\begin{array}{l}\text { Pods } \\
\text { plant }^{-1}\end{array}$ & $\begin{array}{l}\text { Pod length } \\
\quad(\mathrm{cm})\end{array}$ & $\begin{array}{l}\text { No. of } \\
\text { seeds } \\
\text { pods }^{-1}\end{array}$ & $\begin{array}{c}\text { Wt. of } \\
\text { seeds pod } \\
(\mathrm{g})\end{array}$ & $\begin{array}{l}1000 \text {-seed } \\
\text { weight }(\mathrm{g})\end{array}$ & $\begin{array}{l}\text { Seed yield } \\
(\mathrm{kg} / \mathrm{ha})\end{array}$ & $\begin{array}{l}\text { Haulm } \\
\text { yield } \\
\text { (kg/ha) }\end{array}$ \\
\hline \multicolumn{11}{|l|}{ Fertility level } \\
\hline $60 \%$ RDF & 61.91 & 4.39 & 8.13 & 31.98 & 10.48 & 13.59 & 0.178 & 13.28 & 1659 & 3934 \\
\hline $80 \%$ RDF & 67.05 & 5.31 & 9.75 & 34.80 & 11.36 & 14.67 & 0.201 & 14.11 & 2000 & 4677 \\
\hline $100 \%$ RDF & 70.27 & 5.92 & 10.84 & 36.37 & 12.16 & 15.37 & 0.220 & 14.78 & 2245 & 5236 \\
\hline SEm \pm & 0.72 & 0.07 & 0.11 & 0.35 & 0.12 & 0.13 & 0.002 & 0.14 & 24 & 62 \\
\hline $\mathrm{CD}(\mathrm{P}=0.05)$ & 2.08 & 0.20 & 0.32 & 1.00 & 0.35 & 0.39 & 0.007 & 0.39 & 69 & 178 \\
\hline \multicolumn{11}{|l|}{ Biofertilizers } \\
\hline Rhizobium & 67.01 & 5.33 & 9.72 & 33.76 & 11.09 & 14.31 & 0.198 & 13.91 & 1934 & 4597 \\
\hline PSB & 63.71 & 4.79 & 8.96 & 33.43 & 10.78 & 13.98 & 0.192 & 13.58 & 1885 & 4308 \\
\hline Rhizo.+PSB & 68.50 & 5.50 & 10.03 & 35.96 & 12.13 & 15.33 & 0.210 & 14.68 & 2085 & 4941 \\
\hline SEm \pm & 0.72 & 0.07 & 0.11 & 0.35 & 0.12 & 0.13 & 0.002 & 0.14 & 24 & 62 \\
\hline $\mathrm{CD}(\mathrm{P}=0.05)$ & 2.08 & 0.20 & 0.32 & 1.00 & 0.35 & 0.39 & 0.007 & 0.39 & 69 & 178 \\
\hline \multicolumn{11}{|l|}{ Brassinosteroid } \\
\hline Water spray & 63.64 & 4.92 & 9.55 & 32.98 & 10.79 & 13.84 & 0.185 & 13.79 & 1831 & 4320 \\
\hline BR 0.25 ppm & 66.51 & 5.23 & 9.60 & 34.46 & 11.37 & 14.60 & 0.201 & 14.06 & 1975 & 4636 \\
\hline BR 0.50 ppm & 69.08 & 5.48 & 9.56 & 35.72 & 11.84 & 15.18 & 0.213 & 14.31 & 2098 & 4891 \\
\hline SEm \pm & 0.37 & 0.06 & 0.08 & 0.29 & 0.10 & 0.12 & 0.002 & 0.10 & 12 & 42 \\
\hline $\mathrm{CD}(\mathrm{P}=0.05)$ & 1.05 & 0.16 & NS & 0.83 & 0.27 & 0.33 & 0.006 & 0.28 & 34 & 118 \\
\hline
\end{tabular}

Table.2 Yield attributes and yield as influenced by interaction effect between fertility levels and biofertilizers

\begin{tabular}{|c|c|c|c|c|c|c|c|c|c|c|c|c|}
\hline \multirow[t]{3}{*}{ Fertility level } & \multirow{2}{*}{\multicolumn{3}{|c|}{$\begin{array}{c}\text { Pods/ plant } \\
\text { Biofertilizers }\end{array}$}} & \multirow{2}{*}{\multicolumn{3}{|c|}{$\begin{array}{c}\text { Seeds/pod } \\
\text { Biofertilizers }\end{array}$}} & \multirow{2}{*}{\multicolumn{3}{|c|}{$\begin{array}{c}\text { Seed weight } / \text { pod }(\mathrm{g}) \\
\text { Biofertilizers }\end{array}$}} & \multirow{2}{*}{\multicolumn{3}{|c|}{$\begin{array}{c}\text { Seed yield (kg/ha) } \\
\text { Biofertilizers }\end{array}$}} \\
\hline & & & & & & & & & & & & \\
\hline & Rhizo. & PSB & $\begin{array}{l}\text { Rhizo. } \\
\text { + PSB }\end{array}$ & Rhizo. & PSB & $\begin{array}{l}\text { Rhizo.+ } \\
\text { PSB }\end{array}$ & Rhizo. & PSB & $\begin{array}{l}\text { Rhizo.+ } \\
\text { PSB }\end{array}$ & Rhizo. & PSB & $\begin{array}{l}\text { Rhizo.+ } \\
\text { PSB }\end{array}$ \\
\hline $60 \%$ RDF & 31.15 & 30.42 & 34.37 & 13.68 & 13.14 & 13.94 & 0.183 & 0.174 & 0.178 & 1672 & 1609 & 1697 \\
\hline $80 \%$ RDF & 34.56 & 33.24 & 36.62 & 14.17 & 13.84 & 16.00 & 0.195 & 0.184 & 0.224 & 1898 & 1833 & 2270 \\
\hline $100 \%$ RDF & 35.58 & 36.63 & 36.89 & 15.07 & 14.97 & 16.06 & 0.215 & 0.217 & 0.229 & 2233 & 2214 & 2287 \\
\hline $\mathrm{SEm} \pm$ & \multicolumn{3}{|c|}{0.60} & \multicolumn{3}{|c|}{0.23} & \multicolumn{3}{|c|}{0.004} & \multicolumn{3}{|c|}{42} \\
\hline $\mathrm{CD}(\mathrm{P}=0.05)$ & \multicolumn{3}{|c|}{1.74} & \multicolumn{3}{|c|}{0.67} & \multicolumn{3}{|c|}{0.011} & \multicolumn{3}{|c|}{120} \\
\hline
\end{tabular}




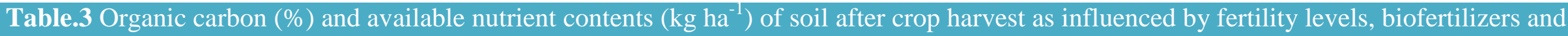
brassinosteroid

\begin{tabular}{|c|c|c|c|c|c|c|c|c|c|c|c|c|c|c|c|}
\hline \multirow[t]{2}{*}{ Treatments } & \multicolumn{3}{|c|}{$\mathrm{OC}(\%)$} & \multicolumn{3}{|c|}{ Available N } & \multicolumn{3}{|c|}{ Available P } & \multicolumn{3}{|c|}{ Available K } & \multicolumn{3}{|c|}{ Available S } \\
\hline & $\begin{array}{c}2012- \\
13\end{array}$ & $\begin{array}{c}2013- \\
14\end{array}$ & Pooled & $\begin{array}{c}2012- \\
13\end{array}$ & $\begin{array}{c}2013- \\
14\end{array}$ & Pooled & $\begin{array}{c}2012- \\
13\end{array}$ & $\begin{array}{c}2013- \\
14\end{array}$ & Pooled & $\begin{array}{c}2012- \\
13\end{array}$ & $\begin{array}{c}2013- \\
14\end{array}$ & Pooled & $\begin{array}{c}2012- \\
13\end{array}$ & $\begin{array}{c}2013- \\
14\end{array}$ & Pooled \\
\hline \multicolumn{16}{|l|}{ Fertility levels } \\
\hline $\mathrm{F}_{1}: 60 \% \mathrm{RDF}$ & 0.282 & 0.302 & 0.292 & 157.16 & 161.65 & 159.41 & 7.88 & 8.39 & 8.13 & 195.01 & 193.28 & 194.14 & 18.54 & 18.72 & 18.63 \\
\hline $\mathrm{F}_{2}: 80 \% \mathrm{RDF}$ & 0.299 & 0.316 & 0.308 & 165.01 & 169.31 & 167.16 & 8.62 & 9.03 & 8.83 & 192.98 & 191.90 & 192.44 & 19.04 & 19.24 & 19.14 \\
\hline $\mathrm{F}_{3}: 100 \% \mathrm{RDF}$ & 0.313 & 0.329 & 0.321 & 172.10 & 176.57 & 174.34 & 9.17 & 9.63 & 9.40 & 192.77 & 190.51 & 191.64 & 19.47 & 19.79 & 19.63 \\
\hline SEm \pm & 0.004 & 0.004 & 0.003 & 2.07 & 2.32 & 1.55 & 0.13 & 0.13 & 0.09 & 2.61 & 2.71 & 1.88 & 0.23 & 0.28 & 0.18 \\
\hline $\mathrm{CD}(\mathrm{P}=0.05)$ & 0.011 & 0.012 & 0.008 & 6.20 & 6.96 & 4.48 & 0.39 & 0.39 & 0.26 & NS & NS & NS & 0.70 & 0.83 & 0.52 \\
\hline \multicolumn{16}{|l|}{ Biofertilizers } \\
\hline $\mathrm{B}_{1}$ : Rhizobium & 0.296 & 0.313 & 0.305 & 166.41 & 170.68 & 168.54 & 8.06 & 8.57 & 8.32 & 193.10 & 191.50 & 192.30 & 19.01 & 19.17 & 19.09 \\
\hline $\mathrm{B}_{2}:$ PSB & 0.290 & 0.306 & 0.298 & 157.15 & 162.02 & 159.59 & 8.76 & 9.18 & 8.97 & 195.79 & 194.21 & 195.00 & 19.18 & 19.52 & 19.35 \\
\hline $\begin{array}{l}\text { B }_{3} \text { : } \\
\text { Rhizobium+PSB }\end{array}$ & 0.308 & 0.328 & 0.318 & 170.70 & 174.84 & 172.77 & 8.86 & 9.29 & 9.08 & 191.87 & 189.97 & 190.92 & 18.86 & 19.07 & 18.96 \\
\hline SEm \pm & 0.004 & 0.004 & 0.003 & 2.07 & 2.32 & 1.55 & 0.13 & 0.13 & 0.09 & 2.61 & 2.71 & 1.88 & 0.23 & 0.28 & 0.18 \\
\hline $\mathrm{CD}(\mathrm{P}=0.05)$ & 0.011 & 0.012 & 0.008 & 6.20 & 6.96 & 4.48 & 0.39 & 0.39 & 0.26 & NS & NS & NS & NS & NS & NS \\
\hline Interaction (FXB) & NS & NS & NS & NS & NS & NS & NS & NS & NS & NS & NS & NS & NS & NS & NS \\
\hline \multicolumn{16}{|l|}{ Brassinosteroid } \\
\hline $\mathrm{G}_{0}:$ Water spray & 0.294 & 0.311 & 0.302 & 162.67 & 166.98 & 164.83 & 8.61 & 9.15 & 8.88 & 195.82 & 193.55 & 194.68 & 18.98 & 19.39 & 19.18 \\
\hline $\mathrm{G}_{1}:$ BR 0.25 ppm & 0.298 & 0.317 & 0.308 & 165.08 & 169.44 & 167.26 & 8.61 & 8.99 & 8.80 & 192.91 & 191.66 & 192.28 & 19.15 & 19.24 & 19.19 \\
\hline $\mathrm{G}_{2}:$ BR $0.50 \mathrm{ppm}$ & 0.302 & 0.318 & 0.310 & 166.51 & 171.11 & 168.81 & 8.45 & 8.91 & 8.68 & 192.04 & 190.47 & 191.26 & 18.91 & 19.12 & 19.02 \\
\hline SEm \pm & 0.003 & 0.003 & 0.002 & 1.53 & 1.85 & 1.20 & 0.12 & 0.13 & 0.09 & 2.09 & 2.18 & 1.51 & 0.17 & 0.25 & 0.15 \\
\hline $\mathrm{CD}(\mathrm{P}=0.05)$ & NS & NS & NS & NS & NS & NS & NS & NS & NS & NS & NS & NS & NS & NS & NS \\
\hline Interactions & NS & NS & NS & NS & NS & NS & NS & NS & NS & NS & NS & NS & NS & NS & NS \\
\hline $\begin{array}{l}\text { (FXG, BXG \& } \\
\text { FXBXG) }\end{array}$ & & & & & & & & & & & & & & & \\
\hline
\end{tabular}

Note: Soil fertility parameters before experimentation were $0.28 \%$ OC, $151.28 \mathrm{~kg} \mathrm{~N}, 7.81 \mathrm{~kg} \mathrm{P}, 197.12 \mathrm{~kg} \mathrm{~K}$ and $18.39 \mathrm{~kg}$ S/ha. 
The highest values of seed (2098 kg/ha) and haulm yield (4891 kg/ha) were recorded under BR $0.50 \mathrm{ppm}$ which were 6.2 and 14.6, and 5.5 and 13.2 per cent higher over 0.25 ppm BR and water spray, respectively. Improvement in yield attributes and thereby yield ascribed to association of brassinosteroid with enhanced photosynthetic efficiency and transport of photosynthates to reproductive parts (Mandava 1988). These results are in close accordance with Farahat (2002) and Bera and Pramanik (2013).

\section{Soil fertility}

Soil fertility parameters (OC \%, available N, $\mathrm{P}$ and $\mathrm{S}$ ) analysed after crop harvest registered significant improvement over the values recorded prior to experimentation with successive higher fertility level from 60 to $100 \%$ RDF. The highest pooled OC \% (0.321), available N (174.34 kg/ha), P (9.40 $\mathrm{kg} / \mathrm{ha})$ and $\mathrm{S}$ (19.63kg/ha.) were recorded from $100 \%$ RDF which were significantly higher over 80 and $60 \% \mathrm{RDF}$, however, $\mathrm{K}$ content was found unaffected. Increasing OC $\%$, available $\mathrm{N}, \mathrm{P}$ and $\mathrm{S}$ at each higher fertility level can be ascribed to higher litter fall and more root mass at higher fertility level. These parameters were recorded higher even at $60 \%$ RDF over the values obtained before experiment which might be due to being a legume crop it builds soil fertility. The results well corroborate with findings of Kumar (2007) and Kumar et al., (2009).

Maximum values of $\mathrm{OC} \%$, available $\mathrm{N}$ and $\mathrm{P}$ at crop harvest were obtained under dual inoculation of Rhizobium and PSB. Coinoculation of Rhizobium and PSB found significantly better over sole Rhizobium and sole PSB in respect of OC\%, and over sole PSB regarding available $\mathrm{N}$, and over sole Rhizobium with respect to available $\mathrm{P}$. Available $\mathrm{K}$ and $\mathrm{S}$ content after crop harvest were found unaffected due to microbial inoculation. It might be due to direct involvement of Rhizobium in $\mathrm{N}$ fixation and PSB in phosphorus solubilisation. Coinoculation of both kinds of bacteria have synergistic effect resulting in higher OC \% due to more root and shoot growth, more $\mathrm{N}$ fixation and phosphorus solubilisation than their sole application. The results conforms the findings of Jat and Shaktawat (2001). Foliar spray of brassinosteroid didn't affect the soil fertility parameters markedly.

\section{References}

Ali Ashif, Sammauria R and Yadav R S. 2009. Response of fenugreek (Trigonella foenum-graecum) to various fertility levels and bio-fertilizer inoculations. Indian Journal of Agricultural Sciences 79 (2): 145-147.

Anonymous 2017. http://nhb.gov.in/statistics/ Publication/Horticulture At a Glance 2017 for net uplod (2). pdf

Bera A K and Pramanik K. 2013. Effect of biofertilizers and homobrassinolide on growth, chlorophyll content, yield, nutrient content and uptake of lentil (Lens culinaris Medik). International Journal of Agriculture, Environment \& Biotechnology 6 (3): 427-436.

Bhunia S R, Chauhan R P S, Yadav B S and Bhati A S. 2006. Effect of phosphorus, irrigation and Rhizobium on productivity, water use and nutrient uptake in fenugreek (Trigonella foenum-graecum). Indian Journal of Agronomy 51 (3): 239-241.

Farahat M M. 2002. Response of fenugreek (Trigonella foenum-graecum L.) plant to foliar application of Brassinosteroid and chelated iron. Arab Universities Journal of Agricultural Sciences 10(1): 181-191.

Godara A S, Singh R and Chouhan G S 2017. Effect of fertility levels, biofertilizers and brassinosteroid on productivity, 
profitability and nutrient uptake of fenugreek (Trigonella foenumgraecum). Indian Journal of Agronomy 62 (1): 94-99.

Jat B L and Shaktawat M S. 2001. Effect of phosphorus, sulphur and bio-fertilizers on yield attributes and yield of fenugreek (Trigonella foenum-graecum L) and their residual effect on pearl millet (Pennisetum gluacum). Indian Journal of Agronomy 46 (4): 627-643.

Khariya K D, Singh B P and Tenja K D. 2003. Effect of farmyard manure and phosphorus

Kumar S, Singh D and Nepalia V. 2009. Performance of fenugreek (Trigonella foenum-graecum) varieties at various fertilizer levels and bio-fertilizer inoculations. Indian Journal of Agricultural Sciences 79 (1) 80-83.

Kumar S. 2007. Performance of fenugreek (Trigonella foenum-graecum L.) varieties at various fertilizer levels and bio-fertilizer inoculation. Ph.D. Thesis, MPUAT, Udaipur (Rajasthan).

levels on yield, quality and nutrient uptake by fenugreek (Trigonella foenumgraecum). Forage Research 28: 210214.

Mandava N B. 1988. Plant growth promoting brassinosteroids. Annals Review of
Plant Physiology and Plant Molecular Biology 39: 23-52.

Mehta R S, Anwer M M, Aishwath O P, Meena R S. 2012. Growth, yield and quality of fenugreek (Trigonella foenum-graecum L.) as influenced by nitrogen, phosphorus and bio-fertilizers. Indian Journal of Horticulture 69(1): 94-97.

Panse V G and Sukhatme P V.1985. Statistical Methods for Agricultural Workers. ICAR, New Delhi.

Purbey S K and Sen N L. 2005. Effect of bioinoculants and bioregulators on productivity and quality of fenugreek (Trigonella foenum-graecum). Indian Journal of Agricultural Sciences 75(9): 608-611.

Purbey S K and Sen N L. 2007. Effect of bioinoculants and bioregulators on yield and nutrient uptake of fenugreek (Trigonella foenum-graecum L.). Indian Journal of Agricultural Research 41(2): 154-156.

Singh D, Nepalia V and Singh A K. 2010. Performance of fenugreek (Trigonella foenum-graecum) varieties at varying fertilizer levels and bio-fertilizers inoculation. Indian Journal of Agronomy 55 (1): 75-78.

\section{How to cite this article:}

Godara, A.S., Ravindra Singh and Chouhan, G.S. 2018. Soil Fertility, Growth and Productivity of Fenugreek (Trigonella foenum-graecum L.) as Influence by Fertilizer Levels, Biofertilizers and Brassinosteroid. Int.J.Curr.Microbiol.App.Sci. 7(09): 462-468.

doi: https://doi.org/10.20546/ijcmas.2018.709.056 